\title{
A comparative evaluation of PCR- based methods for species- specific determination of African animal trypanosomes in Ugandan cattle
}

\author{
Heba A Ahmed ${ }^{1,2}$, Kim Picozzi $^{1}$, Susan C Welburn ${ }^{1}$ and Ewan T MacLeod ${ }^{1 *}$
}

\begin{abstract}
Background: In recent years, PCR has been become widely applied for the detection of trypanosomes overcoming many of the constraints of parasitological and serological techniques, being highly sensitive and specific for trypanosome detection. Individual species-specific multi-copy trypanosome DNA sequences can be targeted to identify parasites. Highly conserved ribosomal RNA (rRNA) genes are also useful for comparisons between closely related species. The internal transcribed spacer regions (ITS) in particular are relatively small, show variability among related species and are flanked by highly conserved segments to which PCR primers can be designed. Individual variations in inter-species length makes the ITS region a useful marker for identification of multiple trypanosome species within a sample.
\end{abstract}

Methods: Six hundred blood samples from cattle collected in Uganda on FTA cards were screened using individual species-specific primers for Trypanosoma congolense, Trypanosoma brucei and Trypanosoma vivax and compared to a modified (using eluate extracted using chelex) ITS-PCR reaction.

Results: The comparative analysis showed that the species-specific primer sets showed poor agreement with the ITS primer set. Using species-specific PCR for Trypanozoon, a prevalence of $10.5 \%$ was observed as compared to $0.2 \%$ using ITS PCR (Kappa $=0.03$ ). For Trypanosoma congolense, the species-specific PCR reaction indicated a prevalence of 0\% compared to 2.2\% using ITS PCR (Kappa =0). For T. vivax, species-specific PCR detected prevalence of 5.7\% compared to $2.8 \%$ for ITS PCR (Kappa $=0.29)$.

Conclusions: When selecting PCR based tools to apply to epidemiological surveys for generation of prevalence data for animal trypanosomiasis, it is recommended that species-specific primers are used, being the most sensitive diagnostic tool for screening samples to identify members of Trypanozoon (T. b. brucei s.l). While ITS primers are useful for studying the prevalence of trypanosomes causing nagana (in this study the species-specific primers did not detect the presence of T. congolense) there were discrepancies between both the species-specific primers and ITS for the detection of T. vivax.

Keywords: Trypanosome, Brucei, Congolense, Vivax, Species-specific PCR, ITS PCR, Nagana

\section{Background}

Routine diagnosis of trypanosomiasis using classical parasitological approaches shows poor sensitivity under field conditions [1]. This is in part, due to the normally very low peripheral parasitemia of naturally infected animals $[2,3]$. The limitations of microscopy for both human and animal

\footnotetext{
* Correspondence: ewan.macleod@ed.ac.uk

'Division of Pathway Medicine and Centre for Infectious Diseases, School of Biomedical Sciences, College of Medicine and Veterinary Medicine, The University of Edinburgh, Chancellor's Building, 49 Little France Crescent, Edinburgh, EH16 4SB, UK

Full list of author information is available at the end of the article
}

trypanosomiasis screening led to the development of a range of serological tests: such as the complement fixation test (CFT), indirect fluorescent antibody test (IFAT), card agglutination test (CATT) and enzyme linked immunosorbant assay (ELISA). However, these methods are unable to differentiate between existing infections and previous exposure to infection, and may lack specificity $[1,4]$.

In recent years, PCR has been widely applied for the detection of trypanosomes and has been shown to be highly sensitive and specific in the laboratory [5]. The use of PCR for detecting trypanosome DNA is the most reliable and accurate technique available for the specific 
identification of natural animal infections for most trypanosome species and sub-species [6,7]. Species-specific DNA targets have been identified for the most important pathogenic trypanosome species that occur in cattle (Trypanosoma brucei s.l., Trypanosoma congolense and Trypanosoma vivax) and PCR based methods for their amplification developed.

For detection of Trypanozoon (Trypanosoma brucei brucei, Trypanosoma brucei gambiense, Trypanosoma brucei rhodesiense, Trypanosoma evansi and Trypanosoma equiperdum), the most common target is the $177 \mathrm{bp}$ DNA satellite repeat sequence originally described by Sloof et al. [8] that exists in high copy number in the parasite genome $(10,000)$. The TBR universal primers developed to amplify the 177 bp sequences from Trypanozoon genomic DNA, were able to detect $0.1 \mathrm{pg}$ of parasite DNA, i.e. the amount of DNA equated to that present in a single trypanosome [9]. Weaker bands containing the $177 \mathrm{bp}$ amplicon, could be detected when the DNA content was as low as $0.01 \mathrm{pg}$ (equivalent to $1 / 10$ th that of a single parasite). Clausen et al. [10] found the TBR primer set able to detect as little as one femtogram of purified DNA (which is equivalent to about $1 \%$ of the genome content of one parasite). In practice, in most cases the universal primers for Trypanozoon are used to identify $T . b$. brucei as a first stage in the process of identifying human infective parasites within an animal population. To further discriminate $T$. $b$. brucei from $T . b$. rhodesiense PCR reactions targeting the single copy serum-resistance-associated (SRA) gene [11] have been developed and applied [6]. To permit discrimination between samples carrying human serum resistant parasites and non human infective parasites a multiplex PCR that simultaneously detects the $S R A$ gene as well as the gene for phospholipase C (GPI-PLC) was developed [12]. Both of these single copy genes are present in $T$. $b$. rhodesiense, but only GPI-PLC is present in T. b. brucei, so if a sample shows positive amplification for GPI-PLC this indicates that sufficient $T$. brucei s.l. genomic material is present to detect a single copy gene while the presence or absence of SRA determines whether $T . b$. rhodesiense is present.

Trypanosoma congolense (savannah) is a highly pathogenic trypanosome that is the most widespread, in terms of both geographical and host range across Sub Saharan Africa [13]. Specific primers designed to detect $T$. congolense, which target a satellite sequence of 316 bp have been developed $[9,14]$. The sensitivity of the universal primers to detect $T$. congolense savannah was $0.1 \mathrm{pg}$ of parasite DNA, again the amount of DNA in a single trypanosome and weak bands containing the amplification product could be detected when the DNA content was $0.01 \mathrm{pg}$ or an estimated 1/10th that of a single parasite [9].

Trypanosoma vivax can be identified using universal primers targeting a fragment of the gene encoding $T$. vivax specific antigen $[15,16]$; this antigen was recognised by a monoclonal antibody (Tv27) in an Ag-ELISA. The cloned gene was found to comprise a tandem repeat, with a monomeric unit length of $900 \mathrm{bp}$ in the genome of all T. vivax isolates from diverse geographic locations in Africa and South America.

These species-specific primers show good sensitivity and specificity against their target species. However, to screen large numbers of samples such as are derived from naturally infected hosts to determine prevalence data, multiple PCRs need to be undertaken for each sample which is both time consuming and expensive. It would be desirable to be able to apply a single PCR reaction that could simultaneously differentiate all of the trypanosome species present within a sample, making screening of a large number of samples viable in terms of time and cost.

Ribosomal RNA (rRNA) genes are highly conserved and have been proved useful for comparisons of closely related species. Eukaryotic rRNA genes occur as tandem repeats of units separated by a non-transcribed spacer (NTS) region and internal transcribed spacer regions (ITS); the ITS regions are relatively small, show variability among related species and are flanked by highly conserved segments to which PCR primers can be designed. Individual variations in inter-species length makes the ITS region a useful marker for species differentiation in trypanosomes and this and their high copy number, of around 200 makes the (ITS) a useful target for species differentiation in trypanosomes and other species $[17,18]$. Njiru et al. [19] and Cox et al. [20] have developed ITSPCR methods that generate a uniquely sized PCR product for each species of trypanosome (the inter-species length variation of the ITS region of ribosomal genes). The protocol developed by Njiru et al. [19] is a single round PCR while Cox et al. [20] is a nested PCR designed to increase sensitivity and specificity. ITS PCR permits multiple trypanosome species to be detected from a single PCR reaction and reduces the cost substantially. Thumbi et al. [21] compared species-specific primer sets with the ITS reactions of Njiru et al. [19] and Cox et al. [20] and found no difference for the diagnosis of Trypanozoon and T. congolense but reported more $T$. vivax positives using the ITS primer sets than were derived using the species-specific primers. The species specific primer set had been developed for West African T. vivax isolates and this could explain the lower levels of positives generated and therefore the disagreement between the ITS PCR tests and species-specific PCR when applied to East African samples. In disagreement with the work of Thumbi et al. [21] a large study of domestic animals from Kenya [22], showed that the speciesspecific primers of Moser et al. [9] were significantly more sensitive and specific than the ITS PCR primers of Cox et al. [20].

Although FTA cards present an efficient method of collection, storage and transportation of field material 
using one punch to seed the PCR reaction can reduce the chances of a positive PCR results [23]. This is due to uneven distribution of parasite DNA on the card and that in order to increase the sensitivity of the PCR an increased number of punches from a card should be tested. However, this is both costly and time consuming. In order to improve the sensitivity of PCR from FTA cards, Ahmed et al. [24] have recently shown that through the use of an elution step simultaneously from 10 punches (each $0.2 \mathrm{~mm}$ ) using Chelex $100^{\circ}$ shows higher sensitivity compared to PCR of 10 punches separately. Therefore in the current work we modified the PCR designed by Cox et al. [20] to include a Chelex $100^{\circ}$ elution stage in order to make the source material comparable.

In this study we have extensively tested a substantive number of cattle samples from Uganda to compare the application of species-specific primer sets targeting Trypanozoon [9,12], T. congolense [14] and T. vivax [14,15] with the Chelex $100^{\circ}$ modified ITS-PCR reaction of Cox et al. [20].

\section{Methods \\ Sample collection}

A total of 600 blood samples were available for testing that had been collected from cattle in Uganda in 2006 from baseline sampling for the Stamp out Sleeping Sickness campaign [25]. Samples came from the following villages, Agwea (Apac district), Abuong B, Amuko Aola, Onyakede (Lira district) and Omid (Kabermaido district). Blood (around $200 \mu \mathrm{l}$ ) was collected from the ear vein and placed on an $\mathrm{FTA}^{\circ}$ card and allowed to dry for 24 hours as described previously $[3,24]$.

\section{Ethical approval}

At the national and district levels, the study was conducted with the approval of the Coordinating Office for Control of Trypanosomiasis in Uganda (COCTU) as well as the District Veterinary Officers (DVOs) in each of the study districts.

\section{Preparation of samples}

In order to allow comparison between the speciesspecific and the ITS-PCR of Cox et al. [20] the protocol of the latter was modified by the addition of a Chelex extraction as described by Becker et al. [26]. Ten discs (each $0.2 \mathrm{~mm}$ ) of the FTA matrix that contain the blood sample were cut and prepared according to the manufacturer's instructions. In order to reduce carryover contamination five blank punches were taken after each sample punch. After washing and drying the discs, DNA was eluted by heating the discs for 30 minutes at $90^{\circ} \mathrm{C}$ in $60 \mu \mathrm{l}$ of $5 \%(\mathrm{w} / \mathrm{v})$ aqueous suspension of Chelex $100^{\circ}$ resin (sodium form, 50-100 dry mesh, Sigma) [26]. For PCR, $5 \mu \mathrm{l}$ of the eluate was added to $20 \mu \mathrm{l}$ of the PCR master mix as described by Ahmed et al. [24] for both the species-specific PCRs and also the modified reaction of Cox et al. [20]. The second round of the nested ITSPCR was seeded with $1 \mu \mathrm{l}$ from the first round.

The species-specific PCR reactions used in this study (see Table 1) detect Trypanozoon DNA (TBR-PCR [9] and GPI-PLC-PCR [12]), T. congolense DNA (TCS-PCR, TCF-PCR, TCK-PCR $[9,14]$ ) and T. vivax DNA (TV-PCR $[14,15])$. The band sizes amplified by the ITS-PCR of Cox et al. [20] are shown in Table 1.

One positive control (genomic DNA) for each trypanosome species was used in the corresponding species specific PCR, while for ITS-PCR, a positive control of T. brucei s.l was used. Negative controls consisting of water only instead of eluate and washed blank discs were run with each PCR.

Amplification products were resolved in $1 \%(\mathrm{w} / \mathrm{v})$ agarose gels along with $100 \mathrm{bp}$ molecular weight Superladder (ABgene, Epsom, Surrey, UK). The agarose gel was prepared in $1 \times \mathrm{TBE}(89 \mathrm{mM}$ Tris-Borate, $2 \mathrm{mM}$ EDTA, and pH 8.3) (Sigma-Aldrich, Poole, Dorset, UK) stained with $5 \mu \mathrm{M}$ ethidium bromide. The gels were run in $1 \mathrm{xTBE}, 5 \mu \mathrm{M}$ ethidium bromide for at least 45 minutes at 100 volts and visualized under an ultra violet transilluminator (Gel-Doc 2000, Bio-Rad).

When the amplification reaction gave a signal of the expected size according to the set of primers used without any signal in the negative control, infection was considered to be confirmed.

\section{Data analysis}

Kappa values were used to determine the level of agreement between the diagnostic tests [27,28]. A Fleiss's Kappa from rating scores using the website of Statstodo. com (http://www.statstodo.com/CohenKappa_Pgm.php) was used to compare the three PCR reactions targeting the Trypanozoon. All other Kappa tests were conducted using WinPepi (Version 3.15 [29]) with a value of above 0.75 indicating excellent agreement, $0.60-0.74$ good agreement, $0.40-0.59$ indicating fair agreement and below 0.40 indicating poor agreement [30].

\section{Results}

\section{Trypanozoon}

A comparison of the sensitivity of the different PCR reactions in the diagnosis of Trypanozoon, species-specific PCR using TBR detected 63 (10.5\% prevalence, 95\% confidence interval $(\mathrm{CI})=8.2 \%-13.2 \%)$ parasitic events, GPI-PLC-PCR detected 46 (7.7\% prevalence, $95 \% \mathrm{CI}=5.7 \%-10.1 \%)$ parasitic events while ITS-PCR detected 1 ( $0.2 \%$ prevalence, 95\% CI $=0 \%-0.9 \%$ ) parasitic events (see Table 2). TBRPCR and PLC-GPI-PCR agreed positively on 46 samples with TBR-PCR detecting an additional 17 samples as being positive. TBR-PCR, GPI-PLC-PCR and ITS-PCR 
Table 1 Different PCR reactions used in the current study

\begin{tabular}{|c|c|c|c|c|c|}
\hline PCR (reference) & Diagnosed species & $\begin{array}{l}\text { Product size } \\
\text { (bp) }\end{array}$ & Primer sequence & Number of cycles & Reaction conditions \\
\hline \multirow[t]{2}{*}{ GPI-PLC-PCR [12] } & \multirow[t]{2}{*}{ Trypanozoon } & \multirow[t]{2}{*}{$324 \mathrm{bp}$} & $\begin{array}{l}\text { 657: 5'- CGC TTT GTT GAG } \\
\text { GAG CTG CAA GCA-3' }\end{array}$ & \multirow[t]{2}{*}{40} & \multirow{2}{*}{$\begin{array}{l}95^{\circ} \mathrm{C} \text { for } 15 \mathrm{~min} \text { then } 94^{\circ} \mathrm{C} \text { for } \\
30 \mathrm{sec}, 63^{\circ} \mathrm{C} \text { for } 90 \mathrm{sec}, 72^{\circ} \mathrm{C} \\
\text { for } 70 \mathrm{sec}, 72^{\circ} \mathrm{C} \text { then for } 10 \mathrm{~min}\end{array}$} \\
\hline & & & $\begin{array}{l}\text { 658: 5'- TGC CAC CGC AAA } \\
\text { GTC GTT ATT TCG-3' }\end{array}$ & & \\
\hline \multirow[t]{2}{*}{ TBR-PCR [9] } & \multirow[t]{2}{*}{ Trypanozoon } & \multirow[t]{2}{*}{$173 \mathrm{bp}$} & $\begin{array}{l}\text { TBR1: 5'-CGA ATG AAT ATT } \\
\text { AAA CAA TGC GCA GT-3' }\end{array}$ & \multirow[t]{2}{*}{35} & \multirow{2}{*}{$\begin{array}{l}94^{\circ} \mathrm{C} \text { for } 3 \text { min then } 94^{\circ} \mathrm{C} \text { for } \\
1 \mathrm{~min}, 55^{\circ} \mathrm{C} \text { for } 1 \text { min, } 72^{\circ} \mathrm{C} \text { for } \\
30 \mathrm{sec} \text {, then } 72^{\circ} \mathrm{C} \text { for } 5 \text { min. }\end{array}$} \\
\hline & & & $\begin{array}{l}\text { TBR2: 5'-AGA ACC ATT TAT } \\
\text { TAG CTT TGT TGC-3' }\end{array}$ & & \\
\hline \multirow[t]{2}{*}{ TCS-PCR [14] } & \multirow[t]{2}{*}{$\begin{array}{l}\text { T. congolense } \\
\text { savannah }\end{array}$} & \multirow[t]{2}{*}{$316 \mathrm{bp}$} & $\begin{array}{l}\text { TCS1: 5'-CGA GAA CGG GCA } \\
\text { CTा TGC GA-3' }\end{array}$ & \multirow[t]{2}{*}{35} & \multirow{2}{*}{$\begin{array}{l}94^{\circ} \mathrm{C} \text { for } 3 \text { min then } 94^{\circ} \mathrm{C} \text { for } \\
1 \text { min, } 60^{\circ} \mathrm{C} \text { for } 2 \min , 74^{\circ} \mathrm{C} \\
\text { for } 30 \mathrm{~s} .\end{array}$} \\
\hline & & & $\begin{array}{l}\text { TCS2: 5'-GGA CAA ACA AAT } \\
\text { CCC GGGCA CA-3' }\end{array}$ & & \\
\hline \multirow[t]{2}{*}{ TCK [14] } & \multirow[t]{2}{*}{ T. congolense kilifi } & \multirow[t]{2}{*}{$294 \mathrm{bp}$} & $\begin{array}{l}\text { TCK1: 5'- GTG CCC AAA TTT } \\
\text { GAA GTG AT-3' }\end{array}$ & \multirow[t]{2}{*}{35} & \multirow{2}{*}{$\begin{array}{l}94^{\circ} \mathrm{C} \text { for } 3 \text { min then } 94^{\circ} \mathrm{C} \text { for } \\
1 \mathrm{~min}, 60^{\circ} \mathrm{C} \text { for } 2 \min , 74^{\circ} \mathrm{C} \\
\text { for } 30 \mathrm{~s} .\end{array}$} \\
\hline & & & $\begin{array}{l}\text { TCK2: 5'- ACT CAA AAT CGT } \\
\text { GCA CCT CG-3' }\end{array}$ & & \\
\hline \multirow[t]{2}{*}{ TCF [14] } & \multirow[t]{2}{*}{ T. congolense forest } & \multirow[t]{2}{*}{$350 \mathrm{bp}$} & $\begin{array}{l}\text { TCF: 5'- GGA CAC GCC AGA } \\
\text { AGG TAC TT-3' }\end{array}$ & \multirow[t]{2}{*}{35} & \multirow{2}{*}{$\begin{array}{l}94^{\circ} \mathrm{C} \text { for } 3 \text { min then } 94^{\circ} \mathrm{C} \text { for } \\
1 \text { min, } 60^{\circ} \mathrm{C} \text { for } 2 \min , 74^{\circ} \mathrm{C} \\
\text { for } 30 \mathrm{~s} .\end{array}$} \\
\hline & & & $\begin{array}{l}\text { TCF2: 5'- GTT CTC GCA CCA } \\
\text { AAT CCA AC-3' }\end{array}$ & & \\
\hline \multirow[t]{2}{*}{ TV-PCR [16] } & \multirow[t]{2}{*}{ T. vivax } & \multirow[t]{2}{*}{$400 \mathrm{bp}$} & $\begin{array}{l}\text { ILO1264: 5'-CAG CTC GGC } \\
\text { GAA GGC CAC TTC GCT } \\
\text { GGG GTG-3' }\end{array}$ & \multirow[t]{2}{*}{35} & \multirow[t]{2}{*}{$\begin{array}{l}94^{\circ} \mathrm{C} \text { for } 90 \mathrm{~s} \min , 55^{\circ} \mathrm{C} \text { for } \\
90 \mathrm{~s}, 72^{\circ} \mathrm{C} \text { for } 2 \mathrm{~min} .\end{array}$} \\
\hline & & & $\begin{array}{l}\text { ILO1265: 5'-TCG CTA CCA } \\
\text { CAG TCG CAA TCG TCG TCT } \\
\text { CAA GG-3' }\end{array}$ & & \\
\hline \multirow[t]{2}{*}{$\begin{array}{l}\text { West African } \\
\text { TV-PCR [15] }\end{array}$} & \multirow[t]{2}{*}{ T. vivax } & \multirow[t]{2}{*}{$175 \mathrm{bp}$} & $\begin{array}{l}\text { TVW1: 5'-GTG CTC CAT GTG } \\
\text { CCA CGT TG-3' }\end{array}$ & \multirow[t]{2}{*}{35} & \multirow[t]{2}{*}{$\begin{array}{l}94^{\circ} \mathrm{C} \text { for } 1 \mathrm{~min}, 55^{\circ} \mathrm{C} \text { for } 1 \mathrm{~min}, \\
72^{\circ} \mathrm{C} \text { for } 2 \mathrm{~min} .\end{array}$} \\
\hline & & & $\begin{array}{l}\text { TVW2: 5'-CAT ATG GTC TGG } \\
\text { GAG CGG GT-3' }\end{array}$ & & \\
\hline ITS-PCR [20] & T. congolense forest & $1513 \mathrm{bp}$ & ITS1: 5'-GAT TAC GTC CCT & Two rounds, 35 cycles, & $95^{\circ} \mathrm{C}$ for 7 minutes then $94^{\circ} \mathrm{C}$ \\
\hline & T. congolense kilifi & 1422 bp & & $\begin{array}{l}\text { each, the second round } \\
\text { PCR was seeded with }\end{array}$ & $\begin{array}{l}\text { for } 1 \mathrm{~min}, 55^{\circ} \mathrm{C} \text { for } 1 \mathrm{~min}, 1 \mathrm{~L}^{\mathrm{C}} \\
\text { for } 2 \text { minutes. }\end{array}$ \\
\hline & $\begin{array}{l}\text { T. congolense } \\
\text { savannah }\end{array}$ & $1413 \mathrm{bp}$ & $\begin{array}{l}\text { ITS2: 5'-TTG TTC GCT ATC } \\
\text { GGT CTT CC-3' }\end{array}$ & $1 \mu \mathrm{l}$ from the first round & \\
\hline & T. brucei s.l. & $1207-1224 \mathrm{bp}$ & $\begin{array}{l}\text { ITS3: 5'-GGA AGC AAA AGT } \\
\text { CGT AAC AAG G-3' }\end{array}$ & & \\
\hline & T. theileri & $988 \mathrm{bp}$ & ITS4: 5'-TGT TTT CTT TTC CTC & & \\
\hline & T. simiae Tsavo & $954 \mathrm{bp}$ & CC & & \\
\hline & T. simiae & $850 \mathrm{bp}$ & & & \\
\hline & T. vivax & $611 \mathrm{bp}$ & & & \\
\hline
\end{tabular}

agreed positively on one sample with TBR-PCR and GPIPLC-PCR identifying an additional 62 and 45 samples respectively. Fleiss's Kappa from rating scores showed poor agreement between the three PCR reactions (Kappa = $0.3997,95 \%$ confidence interval $=0.3535$ to 0.4459 ) Kappa testing showed excellent agreement between TBR-PCR and GPI-PLC-PCR (Kappa $=0.83,95 \%$ confidence interval $=$ 0.75 to 0.91 ). There was poor agreement between ITSPCR and both TBR-PCR (Kappa $=0.03,95 \%$ confidence interval $=-0.03$ to 0.08$)$ and GPI-PLC-PCR (Kappa $=0.04$, $95 \%$ confidence interval $=-0.04$ to 0.11 ).

\section{T. congolense}

Comparing the sensitivity (see Table 2) of the different PCR reactions in the diagnosis of $T$. congolense, speciesspecific PCR using TCS, TCF and TCK detected $0(0 \%$ prevalence, $95 \% \mathrm{CI}=0 \%-0.6 \%)$ parasitic events while ITSPCR detected 13 (2.2\% prevalence, 95\% CI = 1.2\%-3.7\%). 
Table 2 Comparison of species-specific and the modified ITS-PCR of Cox et al. [20] targeting African trypanosomes

\begin{tabular}{|c|c|c|c|c|c|}
\hline \multirow[t]{2}{*}{ PCR reaction } & & \multicolumn{2}{|l|}{ ITS-PCR } & \multicolumn{2}{|l|}{ GPI-PLC } \\
\hline & & Positive & Negative & Positive & Negative \\
\hline \multirow[t]{2}{*}{ TBR } & Positive & 1 & 62 & 46 & 17 \\
\hline & Negative & 0 & 537 & 0 & 537 \\
\hline \multirow[t]{2}{*}{ GPI-PLC } & Positive & 1 & 45 & & \\
\hline & Negative & 0 & 554 & & \\
\hline \multirow[t]{2}{*}{ TCS/TCF/TCK } & Positive & 0 & 0 & & \\
\hline & Negative & 13 & 587 & & \\
\hline \multirow[t]{2}{*}{ TV } & Positive & 8 & 26 & & \\
\hline & Negative & 9 & 557 & & \\
\hline
\end{tabular}

PCR reactions targeted the following genetic material TBR and GPI-PLC: Trypanozoon DNA; TCS, TCF, TCK: Trypanosoma congolense DNA; TV: Trypanosoma vivax DNA).

The species-specific reactions (TCS-PCR, TCF-PCR and TCK-PCR) and ITS-PCR did not agree positively on any samples with ITS-PCR identifying 13 positives in total. Kappa testing showed poor agreement between the species-specific reactions (TCS-PCR, TCF-PCR and TCK-PCR) and ITS-PCR (Kappa $=0,95 \%$ confidence interval $=-0.00$ to 0.00 ).

\section{T. vivax}

Comparing the sensitivity (see Table 2) of the different PCR reactions in the diagnosis of T. vivax, specific PCR using TV detected 34 (5.7\% prevalence, $95 \% \mathrm{CI}=4 \%$ $7.8 \%)$ parasitic events while ITS-PCR detected 17 (2.8\% prevalence $95 \% \mathrm{CI}=1.5 \%-4.8 \%)$ parasitic events. TV-PCR and ITS-PCR only agreed positively on eight animals with TV-PCR and ITS-PCR identifying a further 26 and nine positives respectively. Kappa testing showed poor agreement between TV-PCR and ITS-PCR (Kappa $=0.29$, 95\% confidence interval $=0.12$ to 0.45 ).

\section{Other trypanosome species}

In addition to these pathogenic trypanosome species, ITS-PCR was able to identify non-pathogenic $T$. theileri species. The reaction diagnosed 46 animals (7.6\%) infected with $T$. theileri. A species-specific PCR reaction that targets $T$. theileri satellite sequence of 500 bp size was developed by Rodrigues et al. [31] and was used in the current study but failed to amplify $T$. theileri DNA (data not shown).

\section{Discussion}

The use of ITS-PCR in diagnosis of African trypanosomes allows the identification of several trypanosome species in the same reaction. This is both a saving in time and cost, as less PCR reactions need to be carried out to gain an understanding of the prevalence of trypanosomes in an area. Although FTA cards have simplified the collection and transport of blood samples [3], often DNA is not spread homogenously over the matrix [23]. Although this can be overcome by taking several punches from each FTA card this can be time consuming and expensive. Elution of DNA from the FTA card can improve the sensitivity of species-specific PCR reactions targeting trypanosomes [24]. In the current work we compared an ITS-PCR first described by Cox et al. [20] modified through the elution of DNA from the FTA card to speciesspecific PCR reactions. There was very little agreement for the three major African trypanosome species between these reactions. Although the modified ITS reaction did not perform well for Trypanozoon it performed much better for the detection of $T$. congolense when compared to species-specific reactions.

In this study, ITS-PCR identified only one $(0.2 \%)$ sample to contain Trypanozoon while the species-specific reaction diagnosed 63 parasitic events. The difference between the sensitivity of ITS-PCR and species-specific PCR reactions observed here might relate to the frequency of the target within the parasite genome. The copy number of ITS target in the genome is 100-200 compared to 10,000 for TBR and the higher sensitivity of the latter reaction could be due to the increased copy number of the target DNA. However, good agreement was seen between TBR and GPI-PLC; with the latter targeting a single copy gene [12] it would seem doubtful that copy number alone is the reason for the lack of agreement between TBR and ITS PCR. Cox et al. [20] compared ITS-PCR with the same primers used in the current study and found that ITS-PCR identified 22\% $(n=245)$ of samples positive for Trypanozoon DNA while TBR-PCR identified 21\% $(n=245)$ of samples; these samples were collected on $\mathrm{FTA}^{\circ}$ cards from cattle in Uganda but PCR was conducted directly on the discs after washing. However, more research by de Clare Bronsvoort et al. [22] had shown the species-specific TBR PCR reaction to be more sensitive than the Cox ITS-PCR when the PCR was seeded with washed discs. The differences between the sensitivities of the two reactions in the current study may be due to the fact that the ITS reaction was optimized to work on washed discs rather than eluted DNA. Although Cox et al. [23] showed a higher sensitivity when several punches were screened individually from the same card this is time consuming and costly. The advantage of using eluted DNA being that a greater volume of the FTA card can be sampled from a single PCR reaction [24]. In contrast, Njiru et al. [19] reported that ITS-PCR using other primer sets were comparable to the species-specific reactions where ITS primers detected $84.9 \%$ (373 cattle and 185 camels were tested) of the samples positive using species-specific primers. The higher sensitivity of ITS primers compared with species-specific primers could be 
attributed to the sample processing method, because Njiru et al. [19] extracted DNA from blood samples with Qiagen extraction kits and $2 \mu \mathrm{l}$ of the extract was used as a template in the PCR reaction. Extraction of DNA directly from blood samples increased the sensitivity for the ITS reaction while elution of DNA from the FTA cards inhibits the ITS PCR. However, although Thumbi et al. [21] extracted of DNA from frozen blood samples using the saltout procedure of Sandbrook et al. [32], the specific PCR and the two ITS reactions only detected low levels of infection with Trypanozoon (1.9-3.9\%).

It was difficult to differentiate between $T$. congolense savannah type, $T$. congolense forest type and $T$. congolense kilifi type using ITS PCR even after prolonged separation time of the bands by electrophoresis. This was attributed to the band sizes of the amplified products of the three types are close to each other (1513 bp, $1422 \mathrm{bp}$ and $1413 \mathrm{bp}$ for $T$. congolense forest, $T$. congolense kilifi and $T$. congolense savannah, respectively). For this reason, any product with a band size above $1400 \mathrm{bp}$ was classified as $T$. congolense species. The PCR reactions specific for $T$. congolense savannah, $T$. congolense forest and T. congolense kilifi were negative for all the examined samples with Kappa testing suggesting poor agreement between the two diagnostic PCR tests. Previously Cox et al. [20] had compared ITS-PCR with species-specific reactions on cattle blood samples collected on FTA ${ }^{\circ}$ cards from Uganda. ITS-PCR identified six samples as T. congolense while only one sample was diagnosed using specific reactions for $T$. congolense savannah. The inability of the speciesspecific PCR reactions to identify the $T$. congolense species diagnosed with ITS-PCR could be explained by the existence of a new $T$. congolense sub-species which is similar to $T$. congolense savannah and T. congolense forest in ITS target, while there is no specific reaction to identify these isolates at present. Isoenzyme analysis by Gashumba et al. [33] had previously shown that $T$. congolense from Uganda was separated from other T. congolense isolates suggesting that further analysis of $T$. congolense from Uganda may be required.

In the present study, universal primers targeting the gene encoding $T$. vivax specific antigen were used for the diagnosis of $T$. vivax species. The universal primer set diagnosed $34 T$. vivax infections while ITS-PCR identified 17 positive samples. Another set of primers targeting satellite DNA sequence were used and none of the samples were positive with these primers (data not shown). This was not unexpected since the primers targeting the satellite sequence are not present in some isolates of T. vivax [16]. Cox et al. [20] identified nine T. vivax infections in cattle blood samples using the primer set amplifying the satellite sequence, while ITS-PCR identified six T. vivax infections. Although Cox et al. [20] found little difference between the ITS-PCR and species-specific PCR, there were very few positive samples making comparisons difficult. It has recently been suggested that the species-specific primer sets for $T$. vivax may not accurately assess the level of infection within wild animal samples from Tanzania [34]. This agrees with the current work, where ITS PCR identified nine samples that were not identified by the speciesspecific primer set.

T. theileri was identified in $7.6 \%$ of samples using the modified nested ITS PCR. The prevalence obtained was similar to that obtained by Cox et al. [20] in a low Trypanozoon prevalence village (3\%) but lower than that seen in a high Trypanozoon prevalence village (47\%). As there were no positive results using the species-specific PCR reaction targeting $T$. theileri it was difficult to gauge the sensitivity of the modified ITS PCR in the current work.

\section{Conclusions}

The present study suggests that for estimating prevalence of Trypanozoon within cattle populations, on samples that are collected on to FTA cards (that includes the zoonotic T. b. rhodesiense) species-specific primers are more suitable in terms of sensitivity. However, as species-specific primers did not identify any $T$. congolense and there were differences in the amplification of $T$. vivax, the ITS reactions of Cox et al. [20] and other ones that are available (for example Njiru et al. [19]) might be of great value for detecting these parasites.

\section{Competing interests}

The authors declare they have no competing interests and the sponsors had no role in the study design, data collection and analysis, decision to publish, or preparation of the manuscript.

\section{Authors' contributions}

HAA carried out the study, the molecular approaches and participated in preparing the manuscript. KP and SCW designed the study supervised the molecular approaches and participated in preparing and editing the manuscript. ETM carried out the statistical analyses and participated in preparing and editing the manuscript. All authors read and approved the final version of the manuscript.

\section{Acknowledgements}

HAA would like to show a sincere gratitude to the Egyptian government represented in the public administration missions and the culture bureau in the United Kingdom for the financial and moral support that had a real impact on my research. SCW and ETM were members of COST Action BM0802, Life or Death of Protozoan Parasites. SCW and KP acknowledge support of DFID Research Into Use Programme, ICONZ, (Integrated Control of Neglected Zoonoses) an EU FP7 project and the BBSRC through CIDLID. We are also grateful to Prof Michael Thrusfield, University of Edinburgh for statistical advice.

\section{Author details}

${ }^{1}$ Division of Pathway Medicine and Centre for Infectious Diseases, School of Biomedical Sciences, College of Medicine and Veterinary Medicine, The University of Edinburgh, Chancellor's Building, 49 Little France Crescent, Edinburgh, EH16 4SB, UK. 'Faculty of Veterinary Medicine, Zagazig University, Zagazig 44611, Egypt.

Received: 14 August 2013 Accepted: 30 October 2013

Published: 1 November 2013 


\section{References}

1. Wastling SL, Welburn SC: Diagnosis of human sleeping sickness: sense and sensitivity. Trends Parasitol 2011, 27:394-402.

2. Masake RA, Njuguna JT, Brown CC, Majiwa PA: The application of PCR-ELISA to the detection of Trypanosoma brucei and T. vivax infections in livestock. Vet Parasitol 2002, 105:179-189.

3. Picozzi K, Tilley A, Fevre EM, Coleman PG, Magona JW, Oditt M, Eisler MC, Welburn SC: The diagnosis of trypanosome infections: applications of novel technology for reducing disease risk. Afr J Biotech 2002, 1:39-45.

4. Luckins AG: Detection of antibodies in trypanoasome-infected cattle by means of microplate enzyme-linked immunosorbant assay. Trop Anim Health Prod 1977, 9:53-62.

5. Gibson W: Species-specific probes for the identification of the African tsetse-transmitted trypanosomes. Parasitol 2009, 136:1501-1507.

6. Welburn SC, Picozzi K, Fèvre EM, Coleman PG, Odiit M, Carrington M, Maudlin I: Identification of human-infective trypanosomes in animal reservoir of sleeping sickness in Uganda by means of serum-resistance-associated (SRA) gene. Lancet 2001, 358:2017-2019.

7. Njiokou F, Simo G, Nkinin SW, Laveissiere C, Herder S: Infection rate of Trypanosoma brucei s.l., T. vivax, T. congolense "forest type", and T. simiae in small wild vertebrates in south Cameroon. Acta Trop 2004, 92:139-146.

8. Sloof P, Menke HH, Caspers MPM, Borst P: Size fractionation of Trypanosoma brucei DNA: localization of the 177-bp repeat satellite DNA and a variant surface glycoprotein gene in a mini-chromosomal DNA fraction. Nucl Acids Res 1983, 11:3889-3901.

9. Moser DR, Cook GA, Ochs DE, Bailey CP, McKane MR, Donelson JE: Detection of Trypanosoma congolense and Trypanosoma brucei subspecies by DNA amplification using the polymerase chain reaction. Parasitol 1989, 99:57-66.

10. Clausen PH, Wiemann A, Patzelt R, Kakaire D, Poetzsch C, Mehlitz D: Use of a PCR assay for the specific and sensitive detection of Trypanosoma spp. in naturally infected dairy cattle in peri-urban Kampala, Uganda. Ann N Y Acad Sci 1988, 849:21-31.

11. Xong HV, Vanhamme L, Chamekh M, Chimfwembe CE, Van Den Abbeele J, Pays A, Van Meirvenne N, Hamers R, De Baetselier P, Pays E: A VSG expression site-associated gene confers resistance to human serum in Trypanosoma rhodesiense. Cell 1998, 95:839-846.

12. Picozzi K, Carrington M, Welburn SC: A multiplex PCR that discriminates between Trypanosoma brucei brucei and zoonotic T. b. rhodesiense. Exp Parasitol 2008, 118:41-46.

13. Hoare CA: The Trypanosomes of Mammals: A Zoological Monograph. Oxford: Blackwell scientific publications; 1972.

14. Masiga DK, Smyth AJ, Hayes P, Bromidge TJ, Gibson WC: Sensitive detection of trypanosomes in tsetse flies by DNA amplification. Int J Parasitol 1992, 22:909-918.

15. Masake RA, Nantulya VM, Pelle R, Makau JM, Gathuo H, ole-MoiYoi OK: A species-specific antigen of Trypanosoma (Duttonella) vivax detectable in the course of infection is encoded by a differentially expressed tandemly reiterated gene. Mol Biochem Parasitol 1994, 64:207-218.

16. Masake RA, Majiwa PAO, Moloo SK, Makau JM, Njuguna JT, Maina M, Kabata J, Ole-MoiYoi OK, Nantulya VM: Sensitive and specific detection of Trypanosoma vivax using the polymerase chain reaction. Exp Parasitol 1997, 85:193-205.

17. Desquesnes M, McLaughlin G, Zoungrana A, Davila AMR: Detection and identification of Trypanosoma of African livestock through a single PCR based on internal transcribed spacer 1 of rDNA. Int J Parasitol 2001, 31:610-614.

18. Desquesnes M, Davila AMR: Applications of PCR-based tools for detection and identification of animal trypanosomes: a review and perspectives. Vet Parasitol 2002, 109:213-231.

19. Njiru ZK, Constantine CC, Guya S, Crowther J, Kiragu JM, Thompson RCA, Davila AMR: The use of ITS1 rDNA PCR in detecting pathogenic African trypanosomes. Parasitol Res 2005, 95:186-192.

20. Cox A, Tilley A, McOdimba F, Fyfe J, Eisler MC, Hide G, Welburn SC: A PCR based assay for detection and differentiation of African trypanosome species in blood. Exp Parasitol 2005, 111:24-29.

21. Thumbi SM, McOdimba FA, Mosi RO, Jung'a JO: Comparative evaluation of three PCR based diagnostic assays for the detection of pathogenic trypanosomes in cattle blood. Parasit Vectors 2008, 1:46.

22. de Clare Bronsvoort BM, von Wissmann B, Fèvre EM, Handel IG, Picozzi K, Welburn SC: No gold standard estimation of the sensitivity and specificity of two molecular diagnostic protocols for Trypanosoma brucei spp. in Western Kenya. PLoS One 2010, 5:e8628.

23. Cox AP, Tosas O, Tilley A, Picozzi K, Coleman P, Hide G, Welburn SC: Constraints to estimating the prevalence of trypanosome infections in East African zebu cattle. Parasit Vectors 2010, 3:82.

24. Ahmed HA, MacLeod ET, Hide G, Welburn SC, Picozzi K: The best practice for preparation of samples from FTA ${ }^{\circ}$ cards for diagnosis of blood borne infections using African trypanosomes as a model system. Parasit Vectors 2011, 4:68.

25. Kabasa JD: Public-private partnership works to stamp out sleeping sickness in Uganda. Trends Parasitol 2007, 23:191-192.

26. Becker S, Franco JR, Simarro PP, Stich A, Abel PM, Steverding D: Real-time PCR for detection of Trypanosoma brucei in human blood samples. Diagn Microbiol Infect Dis 2004, 50:193-199.

27. Cicchetti DV, Sparrow SA: Developing criteria for establishing interrater reliability of specific items: applications to assessment of adaptive behavior. Am J Ment Defic 1981, 86:127-37.

28. Fleiss JL, Levin B, Paik MC: Statistical Methods for Rates and Proportions. 3rd edition. Hoboken: John Wiley \& Sons; 2003.

29. Abramson JH: WINPEPI updated: computer programs for epidemiologists, and their teaching potential. Epidemiol Perspect Innov 2011, 8:1.

30. Altman DG: Practical Statistics for Medical Research. London: Chapman and Hall; 1991.

31. Rodrigues AC, Campaner M, Takata CSA, Dell'Porto A, Milder RV, Takeda GF, Teixeira MMG: Brazilian isolates of Trypanosoma (Megatrypanum) theileri: diagnosis and differentiation of isolates from cattle and water buffalo based on biological characteristics and randomly amplified DNA sequences. Vet Parasitol 2003, 116:185-207.

32. Sambrook J, Fritsch EF, Maniatis T: Molecular Cloning: A Laboratory Manual. 2nd edition. Cold Spring Harbor, N.Y: Cold Spring Harbor Laboratory; 1989

33. Gashumba JK, Baker RD, Godfrey DG: Trypanosoma congolense: the distribution of enzymic variants in east and West Africa. Parasitol 1988, 96:475-486.

34. Auty $\mathrm{H}$, Anderson NE, Picozzi K, Lembo T, Mubanga J, Hoare R, Fyumagwa RD, Mable B, Hamill L, Cleaveland S, Welburn SC: Trypanosome diversity in wildlife species from the Serengeti and Luangwa Valley ecosystems. PLoS Negl Trop Dis 2012, 6:e1828.

doi:10.1186/1756-3305-6-316

Cite this article as: Ahmed et al: A comparative evaluation of PCRbased methods for species- specific determination of African animal trypanosomes in Ugandan cattle. Parasites \& Vectors 2013 6:316.

\section{Submit your next manuscript to BioMed Central and take full advantage of:}

- Convenient online submission

- Thorough peer review

- No space constraints or color figure charges

- Immediate publication on acceptance

- Inclusion in PubMed, CAS, Scopus and Google Scholar

- Research which is freely available for redistribution 